\title{
SECURITIES REGULATION: INSURANCE POLICY ENDORSEMENT CREATING AN INDIRECT INTEREST IN PROFIT SHARING HELD NOT A SECURITY
}

In Olpin v. Ideal National Insurance Co., ${ }^{1}$ the Court of Appeals for the Tenth Circuit declined jurisdiction over claims arising from a complex life insurance policy endorsement, holding that the endorsement did not constitute a "security" or an "investment contract" as those terms are used in the Securities Act of 1933, the Securities Exchange Act of 1934, and the Investment Company Act of $1940 .{ }^{2}$ The endorsement established a policyholder's bonus fund to which the insurance company would annually add variable amounts within fixed minimum and maximum levels for each unit of specified life insurance sold. As early as 1948, two insurance companies began issuing policies which contained an endorsement providing that in consideration for payment of a premium higher than that for regular life insurance policies, the insurance companies would, through 1967, annually set aside in a special fund not less than $\$ 1.00$ and not more than $\$ 2.00$ per thousand dollars of specified life insurance for policies remaining in full force through 1967. The fund thereby created would earn two and one-half per cent annual compound interest. Life insurance included within the specified category included all regular policies except those to which the endorsement was attached and group life insurance. ${ }^{3}$ The actual amount to be set aside within the permissible range was determined on an annual basis by the board of directors, and no limitations were placed upon their investment of the resulting fund. This scheme thus provided two means through which the prospective policyholder anticipated profits: increased sales of specified life insurance and election by the board to deposit an amount near the maximum limit of $\$ 2.00$ per thousand. At the end of the accumulation period, each

1. 419 F.2d 1250 (10th Cir. 1969), cert. denied, 397 U.S. 1074 (1970).

2. 15 U.S.C. $\$ \$ 77$ a-aa $(1964) ; 15$ U.S.C. $\$ 78 \mathrm{a}-\mathrm{hh}(1964) ; 15$ U.S.C. $\$ \S 80 \mathrm{a}-1$ to a52 (1964). See generally 1 L. Loss, Securities Regulation 483-89, 496-501 (2d ed. 1961).

3. The opinion neither states the amount of the increased premium nor explains the rationale for the two exceptions.

4. In determining the precise amount between $\$ 1.00$ and $\$ 2.00$ the directors considered previous earnings from the investment of the additional premiums, the size of the accumulated fund, and the interest thereon. 419 F.2d at 1261. 
policyholder would receive his pro rata share of the bonus fund with compound interest. No prior distributions were permitted except that upon the death of the insured the designated beneficiary would receive the pro rata share of the policy in the accumulated fund as of the date of death. ${ }^{5}$ Since the endorsement was illegal under Utah insurance statutes, ${ }^{6}$ Ideal National Insurance Company became liable for all obligations created by the endorsement. Upon learning of this illegality, Ideal gave each policyholder a choice of four options to obtain a refund of the premiums paid on the endorsement. ${ }^{7}$ Under any option the underlying policies would be continued at a reduced premium. The plaintiffs, composed of policyholders whose endorsements were in full force at the end of the accumulation period and of policyholders who had surrendered their endorsements under one of the options set forth by Ideal, brought this class action in which they sought specific performance of the endorsement or, in the alternative, damages. The complaint alleged that the endorsement constituted a "security" within the meaning of the Investment Company Act of 1940 and the Acts of. 1933 and $1934^{8}$ and that Ideal therefore was an "investment company" within the meaning of the Investment Company Act of 1940.' The plaintiffs further contended that Ideal had failed to register the securities and had made untrue statements of material facts or omitted to state material facts regarding the sale. Finding that Ideal bore the entire risk of loss under the endorsement, ${ }^{10}$ the court of appeals affirmed the Utah district court's holding that the plaintiffs failed to state a claim within the jurisdiction of the district court."1

The Securities Act of $1933^{12}$ includes within its broad definition of a "security" any "investment contract" and any "certificate of interest or participation in any profit-sharing agreement." 13

\section{Id. at 1251 .}

6. The opinion does not explain the nature of the statutory violation.

7. Under the four options the holder would receive either: (1) the total amount of the additional premiums paid on the endorsement; (2) the amount of paid-up life insurance which the premiums would have purchased at the age of the polieyholder on the maturity date of the endorsement or upon execution of a release of all possible claims against Ideal; (3) a specified sum of money; or (4) a comparable amount of paid-up life insurance. $419 \mathrm{F.2d}$ at 1253.

8. 15 U.S.C. $\S \S 80 \mathrm{a}-2(\mathrm{a})(35), 77 \mathrm{~b}(1), 78 \mathrm{c}(\mathrm{a})(10)(1964)$.

9. $I d$. $\S 80 \mathrm{a}-3(\mathrm{a})$.

10. 419 F.2d at 1261 .

11. No. C-170-68 (D. Utah 1968).

12. 15 U.S.C. $\S \S 77 a-a a(1964)$.

13. $I d$. $\S 77 \mathrm{~b}(1)$. 
Although the statute does not define an "investment contract," the courts in establishing guidelines have observed that "Congress did not intend tc adopt a narrow or restrictive concept of [a] security,"14 that "the reach of the Act does not stop with the obvious and commonplace,"15 and that a security "embodies a flexible rather than a static principle, one that is capable of adaptation to meet the countless and variable schemes devised by those who seek the use of the money of others on the promise cf profits."16 Section 3(a)(8) of the 1933 Act, howevcr, exempts "any insurance or endowment policy or annuity contract or optional annuity contract . . .."17 According to the House report, the purpose of this exemption was to make clear "what is already implied in the act, namely, that insurance policies are not to be regarded as securities subject to the provisions of the act."18 Thus, a precise distinction between an investment contract and an insurance policy is not provided by statute or legislative history. Insight as to the proper approach to this problem can be gained by reference to the Act's philosophy that "full disclosure of the details of the enterprise in which the investor is to put his money should be made so that he can intelligently appraise the risks involved." 19

The absence in the 1933 Act of precise definitions of a "security" or an "insurance contract" has necessitated judicial interpretation on several occasions, the result of which has been the formulation of two tests for defining a "security." In the landmark case of SEC v. Variable Annuity Life Insurance Co. ${ }^{30}$ (VALIC), the Supreme Court held that a variable annuity contract is a security rather than insurance ${ }^{21}$ and that the concept of "insurance" requires some investment risk-taking on the part of the company and a guarantee that at least some fraction of the benefits will be payable in fixed amounts. ${ }^{22}$ The opinion appears to hold that insurance

14. Tcherepnin v. Knight, 389 U.S. 332, 338 (1967). For a general discussion of this case see note 27 infra.

15. SEC v. C.M. Joiner Leasing Corp., 320 U.S. 344, 351 (1943).

16. SEC v. W.J. Howey Co., 328 U.S. 293, 299 (1946).

17. 15 U.S.C. $\$ 77 \mathrm{c}(\mathrm{a})(8)(1964)$.

18. H.R. ReP. No. 85, 73d Cong., Ist Sess. 15 (1933).

19. SEC v. Variable Annuity Life Ins. Co., 359 U.S. 65, 77 (1959).

20. 359 U.S. 65 (1959). See generally L. Loss, supra note 2, at 496-501; Martin, The Status of the Variable Annuity as a Security: A Lesson in Legal Line Drawing, 30 Oнı ST. L.J. 736 (1969); Mearns, The Commission, the Variable Annuity, and the Inconsiderate Sovereign, 45 VA L. Rev. 83 I (1959); 38 Texas L. Rev. 248 (1959).

21. 359 U.S. at 71 .

22. Id. 
contracts which do not fulfill these two requirements are "securities." Acknowledging that the variable annuity has elements of both the conventional annuity and a security, Mr. Justice Brennan in his concurring opinion reasoned that the policyholder is putting his funds in the hands of another for investment purposes and that the disclosure requirements of the securities acts should therefore apply in order to protect the policyholder. ${ }^{23}$ This approach reflected the rationale in SEC v. W.J. Howey $\mathrm{Co}_{.}{ }^{24}$ an earlier case involving a contract for the sale of small parcels of a citrus grove development coupled with a contract for cultivating and marketing the crop and remitting the net proceeds to the investor, who neither occupied nor developed the land himself. ${ }^{25}$ The Howey court defined an "investment contract" as a "contract, transaction or scheme whereby a person invests his money in a common enterprise and is led to expect profits solely from the efforts of the promoter or a third party ...."26 The Howey definition was relied on by the Supreme Court in Tcherepnin v. Knight ${ }^{27}$ to find that a withdrawable capital share in a savings and loan association was a "security."28 The Court reasoned that the requirements under the Howey test were met since the amount of dividends were tied directly to the profits of the corporation. ${ }^{29}$ A variation of the $V A L I C$ test was proposed in $S E C$ v. United Benefit Life Insurance $C 0^{30}$ which determined that a more ingenious contract than that in $V A L I C$ also constituted a security despite the reduced risk on the part of the insured. ${ }^{31}$ That contract provided for the payment of monthly premiums into a fund, the major portion of which was invested in common stocks. The purchaser could at any time withdraw all or part of his proportionate share of the fund, or, in the alternative, he could withdraw his cash value which increased from 50 per cent of the net premiums paid after the first year to 100 per cent of premiums paid after ten years. ${ }^{32}$ The Supreme Court noted that this

23. Id. at 85 .

24. 328 U.S. 293 (1946), See L. Loss, supra note 2, at 483-89.

25. 328 U.S. at 299-300.

26. Id. at $298-99$.

27. 389 U.S. 332 (1967). See generally Note, Securities Regulation: Seventh Circuit Holds That Withdrawable Capital Accounts Are Not "Securities" Within the Meaning of the Exchange Act, 1967 DuKE L.J. 1233.

28. 389 U.S. at 338.

29. Id. at 339 .

30. 387 U.S. 202 (1967). See generally 17 BuffaLo L. ReV. 495 (1968).

31. 387 U.S. at 210-11.

32. Id. at 205. 
minimum guaranteed return promised by United was so low that the risk of not being able to meet it through investment was insignificant. ${ }^{33}$ The factor which the court appears to require in finding a security is lack of a substantial investment risk-taking by the issuer ${ }^{34}$ at least where the issuer offers to the public the prospect of growth through professionally managed investment..$^{35}$ Thus, a security is presently held to exist not only where the policyholder expects profits solely from the efforts of others, but also where the issuer has failed to assume either some risk or a substantial risk, the exact extent of the risk required to be assumed by the issuer depending upon the significance of the profit-sharing representations which were present in United Benefit. Although an abstract view of these tests would seem to provide strict requirements for defining a security, analysis of the individual cases reveals that the definitions provided by the courts have only been as far reaching as was required to find a security in the particular factual setting. In practically all cases the courts have adhered to the doctrine of liberal interpretation of what constitutes a security.

Basing its decision primarily on the risk-taking test, the Tenth Circuit in Olpin reasoned that the endorsement was not a "security" because Ideal bore the entire risk and because the policyholders had only an indirect interest in the inviestment experience of Ideal's managers, ${ }^{36}$ since the obligation to pay each proportionate share from the fund was not dependent on Ideal's investment success. ${ }^{37}$ The court thereby emphasized the inability of Ideal to decrease its payments to policyholders, if, upon termination of the fund, Ideal had not realized a profit. The court reasoned further that although the directors gave consideration to the earnings from the investment of the additional premiums, the accumulated fund, and the interest thereon in determining the amount to set aside annually, the amount placed in that fund was final, ${ }^{38}$ so that no matter how poorly the fund performed in the future, the company could never recoup losses by removing amounts previously committed to the fund. The court noted that ldeal carried the entire risk that it might not realize from investment of the fund an aggregate amount sufficient to pay each
33. Id. at 209 .
34. Id. at 210 .
35. Id. at 211 .
36. 419 F.2d at 1262 .
37. Id. at $1260-61$.
38. Id. at 1261 
policyholder his proportionate share of the fund. ${ }^{30}$ The court apparently reasoned that the policyholder's return was not based on profits since Ideal had no obligation to share with the policyholder any net profits from investment of the fund. ${ }^{40}$ The court considered the creation by Ideal of a reserve from which to discharge its obligations under the endorsement as further evidence that the endorsement was an insurance contract. Although conceding that the policy did not provide for fixed amounts of benefits, the Tenth Circuit attached significance to the provision for a fixed mathematical method whereby benefits were determined and to the provision establishing a fixed interest rate. ${ }^{11}$ The court was apparently analogizing these provisions to the fixed rates and fixed methods of return provided by savings accounts which are clearly not securities.

The Tenth Circuit neither acknowledged that the endorsement provided two means whereby an Ideal poicyholder anticipated profits ${ }^{12}$ nor analyzed these two provisions in terms of the tests which the Supreme Court has previously utilized to define a security. By strictly applying these tests, a court might find that the endorsement technically failed to fulfill the requirements of each, but such an approach would ignore the statutory history of liberal interpretation. ${ }^{13}$ The endorsement arguably did not fulfill the requirements of the Howeyt4 test in that the $\$ 1.00$ minimum was a guaranteed return and therefore investor return did not depend solely on the successful efforts of others. Such a literal interpretation of the Howey test would, however, ignore the factual background in Howey, where profits were produced solely by the developer's, and not by the investor's, efforts. The determination which the Howey court considered crucial was whose efforts produced the investor's return and not the extent to which that return depended on the issuer's efforts, as was the case in Olpin regarding the guaranteed return. In Olpin as in Howey the purchaser's return was based solely

39. Id.

40. Id.

41. Id. at 1262-63. At the end of the accumulation period the policyholder was entitled to his proportionate share of the amounts set aside in the fund plus compound interest less amounts paid to beneficiaries. The proportionate share was the number of units in the policy of the surviving policyholder divided by the total number of units in all policies.

42. See notes 5-7 supra and accompanying text.

43. See notes 18-20 supra and accompanying text.

44. See notes 28-30 supra and accompanying text. 
on the efforts of others, since the policyholder would realize no return on his endorsement policy premium unless the issuer was successful in selling the specified policies. An argument can also be made that the endorsement was not a security since the issuer fulfilled the investment risk-taking requirement of $V A L I C{ }^{45}$ The insurance company clearly assumed the risk that payment of the $\$ 1.00$ minimum might result in a loss to the company. A question which the Tenth Circuit never answered but which the United Benefit Court considered important ${ }^{t 6}$ is whether Ideal actually assumed any risk under this provision. Ideal had the right to limit the number of specified policies sold and thus could have adjusted the amount of premiums paid on the endorsement policy and thereby avoided any riș whatsoever. If the total of all adjusted premiums collected on the endorsement policy was greater than the amount of specified life insuranice which ldeal decided to sell divided by $\$ 1,000$, then Ideal would have created a guaranteed profit for itself. Because Ideal could earn interest by placing the fund in a bank account at no risk and because those who failed to fulfill their obligations under the endorsement lost their rights in the fund, including the right of withdrawal of premiums paid, a premium of substantially less than the adjusted premium might still have involved no risk assumption by ldeal. Assuming that $V A L I C$ 's risk assumption requirement was met, the endorsement must still be analyzed in terms of the qualifications developed in United Benefit. ${ }^{17}$ The insurance company must now assume a substantial risk instead of merely some risk, at least in the situation where the issuer represents the endorsement as an opportunity to share in the investment experience of others. As previously suggested, it is questionable whether Ideal assumed any risk whatsoever much less a substantial risk. Further, it is doubtful that a security should not be found to exist where there was a lack of substantial risk taking by the issuer even though no representation of its equity nature was made. Although the United Benefit Court was not faced with that fact situation, liberal interpretation of the securities acts for the purpose of providing the opportunity for informed investment on the basis of full disclosure would appear to mandate such a result. Thus, while a court by strictly construing Howey, VALIC, and United Benefit might find that the

45. See notes 25-26 supra and accompanying text.

46. See note 38 supra and accompanying text.

47. See notes 38-39 supra and accompanying text. 
endorsement did not create a security, the court should consider the possibility that the endorsement created a return so closely related - to net profits that the investor should be protected by the securities laws' disclosure requirements. In combination the two different aspects of the endorsement created an extremely complicated profitmaking scheme, which is susceptible to extensive manipulation by the insurance company and which provides for no control by the investor. Without knowing precisely how the endorsement was actually treated by ldeal, it is impossible to surmise the exact degree to which policyholders were sharing in ldeal's profits and assuming investment risks. Because the provisions could conceivably have resulted in direct profit sharing and substantial policyholder risk assumption, the Tenth Circuit, in holding that the endorsement was not a security, not only has ignored the history of liberal interpretation regarding the definition of a security but also has failed to require disclosure in a situation where the investor is faced with many unknowns. 